\title{
The Effect Of Estrogen On The Male Reproductive System Of Rats Receiving Cimetidine
}

\author{
Ali Saeed Hammodi \\ Veterinary college \\ University of Mosul
\& Sajeda Al-Chalabi
College of medicine
University of Mosul \\ \& \\ Rana A. Asem
}

Received

08 / 03 / 2011
Accepted

01 / 06 / 2011

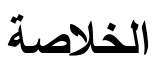

استخدم في هذه الدراسة ب جرذ ذكر بالغ سوي لدراسة مدى تداخل استعمال الاستروجين

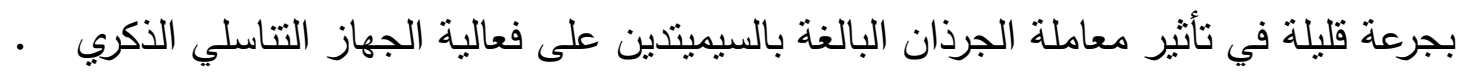

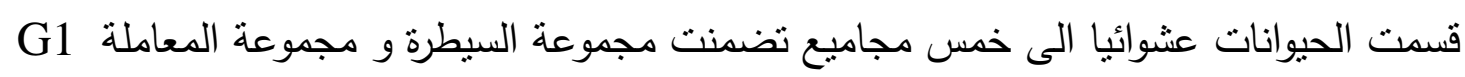

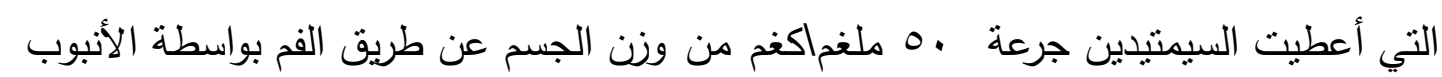

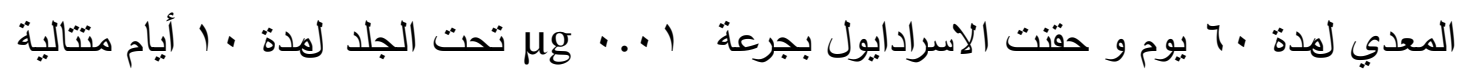

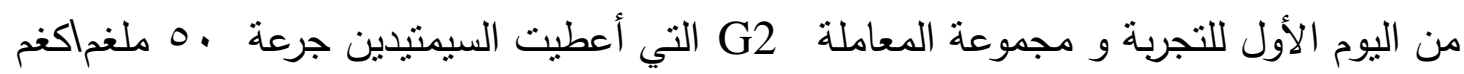

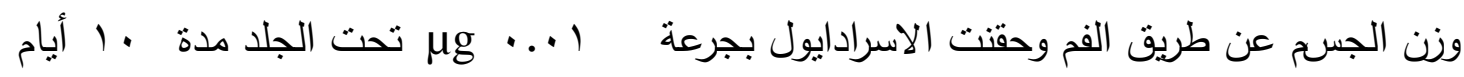

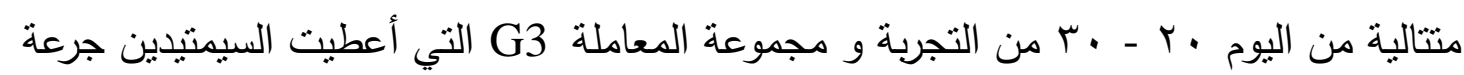

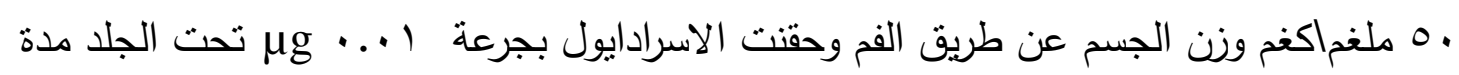

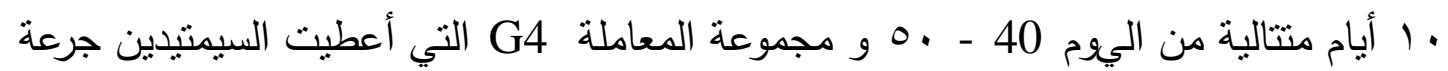

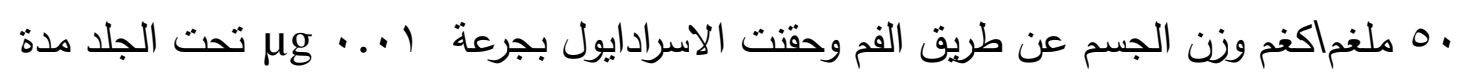

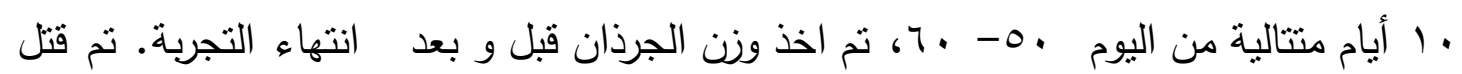

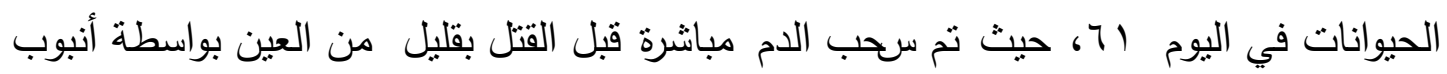
شعري لقياس مستوى هرمون التستوستيرون و FSH في المصل. كذلك تم حساب أوزان الأعضاء

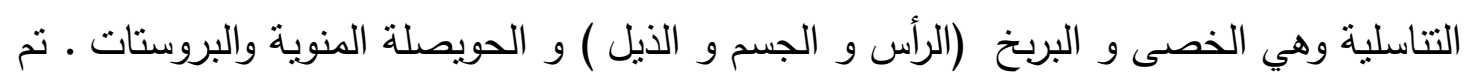

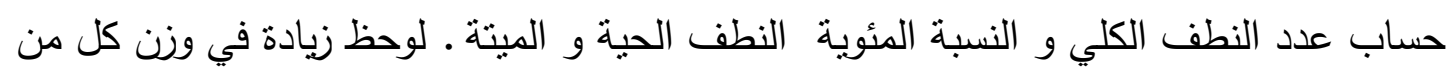

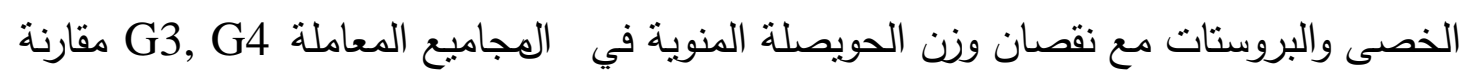




$$
\begin{aligned}
& \text { بمجموعة السيطرة. كما لوحظ زبادة في مستوى هرمون FSH مقارنة بمجموعة السيطرة في حين } \\
& \text { لم يتغير مستوى التستوستيرون طيلة فترة التجربة في كافة الهجاميع. حدث انخفاض في عدد } \\
& \text { النطف الكلية و النسبة المئوية للنطف الحية و زيادة في النسبة المئوية للنطف الميتة مقارنة } \\
& \text { بمجموعة السيطرة. أدى السيمتيدين الى إحداث أذى و تثبيط للجهاز التتاسلي الذكري ولم يتداخل } \\
& \text { الاستروجين في عكس هذا التأثنر الضار • }
\end{aligned}
$$

\section{Abstract}

To show if a small dose of estrogen can interfere with the effect of Cimetidine on male reproductive system. Five groups of five randomly selected adult male rats were utilized. Rats were given food (laboratory rat chow) and water ad libitum. Rats were treated orally with Cimetidine $50 \mathrm{mg} / \mathrm{kg}$ and subcutaneous injection with estradiol $0.01 \mu \mathrm{g}$ for 60 days. The animals were grouped as: group1, treated from days 1-10. Group2, treated from days 20-30. Group3, treated from days 40-50. Group4, treated from days 50-60. Group 5 received no treatment as a control group. Blood samples were taken from the eyes (by using capillary tubes) to measure testosterone (T) and follicular stimulating hormone (FSH) levels. Measurement of weights of the reproductive organs including the testis, epididymis (head, body, and tail), seminal vesicle and prostate were done. Body weight for each animal was recorded before and after treatment. Also we counted the total sperm count and the percentage of dead and alive spermatozoa for the treated groups using Eosin-negrosin stain. The testis weight and prostate weight was significantly increased in both groups 3 and 4, while seminal vesicle weight was significantly reduced. FSH levels were significantly increased, while testosterone levels were unchanged. Total sperm count and a number of a live sperms were significantly reduced and the number of dead sperms was significantly increased among the treated groups. Cimetidine has hazards on male reproductive function while estrogen didn't play any role to abolish this action.

Key Words: testis, spermatogenesis, cimetidine, estrogen.

\section{Introduction}

Cimetidine (Tagamet) is a $\mathrm{H} 2$ receptor antagonist. (Winters et al., 1979) has used initially in the treatment of gastric and duodenal ulcers. It is currently sold "over the counter" to reduce gastric acid secretion and the resulting discomfort as heart burn. Cimetidine has been widely prescribed worldwide during the last $20-30$ years.

A well known side effect of cimetidine is its ability to compete and block dihydrotestosterone (DHT) by occupying the androgen receptor (Winters et al., 1979), making it a weak antiandrogen for tissues requiring DHT. 
The peripheral accessory organ weights are reduced in rodents, probably due to DHT deficiency. The consequences of the loss of DHT activity in the testis are not well known since the role of DHT is currently still under investigation with regards to its ability to support spermatogenesis (Chen et al., 1994; O'Donnell et al., 1996).

The development of male reproductive tract is a dynamic process requiring the interaction of many factors and hormones, one of the major factors essential for the development of the internal and external male reproductive tract are the androgens, testosterone and DHT (Wilson, 1987).

The musculinization of the reproductive structures is mediated by testosterone, the musculinization of the external genitalia and prostate is largely mediated by DHT which is a more potent metabolite of testosterone and is produced by the action of $5 \alpha$ reductase' (Wilson, 1987).

Although it has been known for many years that estrogen administration has deleterious effects on male fertility, data from transgenic deficient in estrogen or aromatase point to an essential physiological role of estrogen in male fertility. The increased interest in the role of estrogens in the male is largely due to the demonstration that male fertility is impaired in mice lacking estrogen alpha receptor (Lubahn et al., 1993; Korach,1994)., aromatase (Robertson et al.,; 1999 Toda et al., 2001).

Despite the huge amount of published data on the response of the testis and spermatogenesis to either estrogen deprivation or estrogen treatment, the exact role for estrogen in spermatogenesis remains unclear. The confusion as to the involvement of estrogen in initiation and maintenance of testicular function and spermatogenesis is likely due to the fact that estrogen action is important at numerous levels in male reproductive physiology including effects on the hypothalamic-pituitary testis axis, Leydig cells, Sertoli cells, germ cells and epididymal function (Meistrich et al., 1975).

In adult rat testis estrogen is synthesized by Leydig cells producing a relatively high concentration in the rete testis fluid and in the semen of several species, estrogen receptors are present in the testis, efferent ductules and epididymis of most species (Hess and Carnes, 2004) points the role of estrogen in the regulation of these tissues and thus in modifying sperm maturation and activation. Estrogen deficiency in the adult rat promotes efferent ductile epididymal dysfunction (Meistrich et al., 1975).

Estrogen beta receptor is found in the Sertoli cells and nearly in all the germ cells (Nie et al., 2002; Sannders et al., 2002).

This study aims to answer two important questions: 
1. Can exposure to estrogen interfere on male fertility when the male is receiving cimetidine?

2. Does estrogen play any role on spermatogenesis?

\section{Materials and Methods}

\section{Animals}

25 adult male albino Wistar rats weighing 230 - 400g were used in accord with the NIH Guide for care and use of laboratory animals. The animal were obtained from libratory animal house of veterinary college and subdivided into five groups. Animals were fed on laboratory rat chow and water given ad libitum. Animals treated with cimetidine (tagadin) and estradiol benzoate (topestradiol $0.2 \%$, supplied by TOPSURF enterprises Inc. Vancouver Canada).

\section{Treatment}

Estradiol was given during different periods in this experiment to determine the best period of estradiol administration in order to reverse the effect of cimetidine on male fertility in rats.

All the animals were given oral daily dose $50 \mathrm{mg}$ cimetidine per $\mathrm{Kg}$ body weight for 60 days.

Group1:The rats of this group received estradiol benzoate $0.01 \mu \mathrm{g} \backslash$ rat subcutaneous injection for 10 days from day 1 - day 10 of experiment with cimetidine $50 \mathrm{mg} \mid \mathrm{kg}$ body weight given orally.

Group2: The rats of this group received estradiol benzoate $0.01 \mu \mathrm{g} \mid$ rat subcutaneous injection starting from days 20 - 30 of experiment with cimetidine $50 \mathrm{mg} \backslash \mathrm{kg}$ body weight also given orally.

Group3: The rats of this group received estradiol benzoate $0.01 \mu \mathrm{g} \backslash \mathrm{rat}$ subcutaneous injection starting from day 40 -50 of experiment with cimetidine $50 \mathrm{mg} \backslash \mathrm{kg}$ body weight were also given orally.

Group4: The rats of this group received estradiol benzoate $0.01 \mu \mathrm{g} \backslash$ rat subcutaneous injection starting from day 50 - 60 of experiment with cimetidine $50 \mathrm{mg} \backslash \mathrm{kg}$ body weight were also given orally.

Group5: The animal of this group were given only normal saline.

\section{Hormone assays}

Blood samples were taken from rat eyes by using capillary tube and collecting blood in plane tubes (without anticoagulant) to obtain serum. (Blood samples were separated by centrifugation at $10000 \mathrm{rpm}$ for 15 minutes), for measuring testosterone (T) and Follicle Stimulating Hormone (FSH) levels. Testosterone in serum of rats was measured by ELISA using a commercial kit (Biocheck, Inc. faster city CA 94404). FSH was measured using a commercial kit (Monobind Inc Lake Forest CA 92630 USA). 


\section{Organ Weights}

Recording the weights of the reproductive organs including the testis, epididymis, seminal vesicle and prostate were done (using Sartorius "BL210S" balance) Sartorius AG GÖTTNGEN Germany. Body weight for each animal was recorded before and at the end of each experiment.

Also we estimate total sperm count (Sakamato and Hashimoto, 1980) and the percentage of dead and a live spermatozoa for the treated groups (Luna, 1968; Noakes and Parkison, 2001) using Eosin - negrosin stain.

Statistics: All data were presented as Mean \pm S.E of mean and analyzed via SPSS version 11.5 software ONE-WAY ANOVA test. The significance level for comparisons was considered to be $>0.05$. أبو زيد) $r \cdot 1 \cdot)$

\section{Results}

There was no statistical significant difference in body weight before and at the end of treatment (see table 1).

Table 1: Comparison of Mean $\pm \mathrm{S}$.E of body weight of rats in gram between control group and treated groups using ANOVA.

\begin{tabular}{|c|c|c|c|c|c|}
\hline $\begin{array}{c}\text { After 60 } \\
\text { days }\end{array}$ & $\begin{array}{c}\text { After 45 } \\
\text { days }\end{array}$ & $\begin{array}{c}\text { After 30 } \\
\text { days }\end{array}$ & $\begin{array}{c}\text { After 15 } \\
\text { days }\end{array}$ & Zero time & $\begin{array}{c}\text { Parameter } \\
\text { Groups }\end{array}$ \\
\hline $331.8 \pm 23.6$ & $325.4 \pm 16.7$ & $312.2 \pm 12.6$ & $299.6 \pm 5.1$ & $259.2 \pm 9.1$ & Control \\
\hline $330.4 \pm 18.6$ & $326 \pm 21.7$ & $317.2 \pm 22$ & $308.6 \pm 24.3$ & $315.4 \pm 15.9$ & G 1 \\
\hline $374.4 \pm 20.7$ & $370 \pm 26.3$ & $364 \pm 22.9$ & $356.8 \pm 26.7$ & $309.4 \pm 32.1$ & G 2 \\
\hline $340 \pm 16.3$ & $341.2 \pm 16.3$ & $331.8 \pm 15.4$ & $314 \pm 16.5$ & $301 \pm 17.3$ & G 3 \\
\hline $350.2 \pm 26.8$ & $337.4 \pm 22$ & $326 \pm 23.8$ & $319.2 \pm 24.5$ & $314.2 \pm 27.4$ & G 4 \\
\hline
\end{tabular}

Numbers represent Mean \pm S.E.

The weight of testis in G1 and G2 was not statistically different from the control group while there was a significant increase in testis weight in G3 and G4 as compared with control group (see table 2).

There was no significant difference in the weight of the head of epididymis in $\mathrm{mg} / 100 \mathrm{~g}$ body weight in all groups as compared with control group. 
The weight of the body of the epididymis was significantly different in group4 as compared with control, while there was no statistical difference in G1, G2, G3 from the control group.

The weight of the tail of the epididymis was not statistically different in the treated groups as compared to the control group.

A trend toward a decrease in the weight of the seminal vesicle was noted and it was statistically significant in treated groups as compared to the control group.

The weight of the prostate was significantly increased in G2, G3 and G4 as compared to control group while in G1 there was no statistical difference from the control group.

Table 2: Comparison of Mean \pm S.E of organ weights in treated groups and control group $\mathrm{mg} / 100 \mathrm{~g}$ body weight using ANOVA $; \mathbf{n}=5$ for each group.

\begin{tabular}{|c|c|c|c|c|c|c|}
\hline \multirow[t]{2}{*}{ Prostate } & \multirow{2}{*}{$\begin{array}{c}\text { Seminal } \\
\text { vesicle }\end{array}$} & \multirow[t]{2}{*}{ Testis } & \multicolumn{3}{|c|}{ Epididymis (mg \100g BW) } & \multirow{2}{*}{$\begin{array}{l}\text { Organ } \\
\text { weig) } t \\
(\mathrm{mg})\end{array}$} \\
\hline & & & Tail & Body & Head & \\
\hline $327.83 \pm 33.63$ & $179.47 \pm 4.96$ & $306.08 \pm 15.46$ & $70.39 \pm 13.85$ & $12.82 \pm 1.37$ & $84.96 \pm 18.95$ & control \\
\hline $338.98 \pm 31.20$ & $154.51 \pm 10.02 *$ & $311.36 \pm 21.00$ & $102.38 \pm 33.51$ & $13.19 \pm 1.06$ & $71.99 \pm 9.74$ & G 1 \\
\hline $281.51 \pm 32.64 *$ & $125.68 \pm 6.7 *$ & $338.19 \pm 17.25$ & $78.32 \pm 23.06$ & $12.61 \pm 1.54$ & $64.62 \pm 10.91$ & G 2 \\
\hline $355.15 \pm 40.34 *$ & $157.12 \pm 17.55^{*}$ & $309.59 \pm 44.95 *$ & $69.81 \pm 26.97$ & $10.97 \pm 2.34$ & $70.38 \pm 19.68$ & G 3 \\
\hline $428.32 \pm 63.99 *$ & $165.32 \pm 23.99 *$ & $411.44 \pm 31.98 *$ & $56.55 \pm 6.45$ & $16.83 \pm 1.95 *$ & $61.59 \pm 6.34$ & G 4 \\
\hline
\end{tabular}

Numbers represent Mean \pm S.E $*$ mean significant $\mathrm{p} \leq 0.05$.

Table 3 shows that the total sperm count significantly reduced in all the treated groups as compared to control group. There was a statistical significant decrease in the \% of a live sperms in G1, G2 and G3 as compared to control group while no significant difference between G4 and the control group.

There was a significant increase in the number of the \% of a dead sperms in G1, G2 and G3 as compared to the control group while there was no significant difference between G4 and the control group.

FSH levels were significantly increased in all groups as compared to the control group. There was no significant difference in testosterone levels in all groups as compared to the control group. (see table 3 ) 
Table 3: Comparison of Mean $\pm S$.E of number of sperms, a live and dead sperms in groups and control group using ANOVA.

\begin{tabular}{|c|c|c|c|c|c|}
\hline $\begin{array}{c}\text { Testosterone } \\
(\mathbf{n g} / \mathbf{m l})\end{array}$ & FSH $(\boldsymbol{\mu g} / \mathbf{m l})$ & $\begin{array}{c}\text { Dead } \\
\text { sperm\% }\end{array}$ & $\begin{array}{c}\text { A live } \\
\text { sperm\% }\end{array}$ & $\begin{array}{c}\text { Sperm } \\
\text { count }(\times \mathbf{1 0} / \mathbf{m l})\end{array}$ & $\begin{array}{c}\text { Parameter } \\
\text { groups }\end{array}$ \\
\hline $7.87 \pm 0.90$ & $5.48 \pm 0.40$ & $24.40 \pm 3.64$ & $75.60 \pm 3.64$ & $2.08 \pm 0.14$ & control \\
\hline $6.88 \pm 1.41$ & $11.90 \pm 0.97 * *$ & $49.00 \pm 4.28^{* *}$ & $51.00 \pm 4.28 * *$ & $1.00 \pm 0.10^{* *}$ & G 1 \\
\hline $7.37 \pm 0.74$ & $9.51 \pm 0.55^{*}$ & $56.00 \pm 2.75^{* *}$ & $44.80 \pm 5.07 * *$ & $0.82 \pm 0.04 * *$ & $\mathbf{G ~ 2}$ \\
\hline $8.45 \pm 1.18$ & $11.08 \pm 1.23 * *$ & $57.00 \pm 3.61 * *$ & $42.20 \pm 4.11 * *$ & $0.67 \pm 0.04 * *$ & $\mathbf{G ~ 3}$ \\
\hline $7.63 \pm 0.98$ & $13.90 \pm 1.89 * *$ & $23.40 \pm 1.24$ & $73.00 \pm 2.9$ & $1.29 \pm 0.06^{*}$ & $\mathbf{G 4}$ \\
\hline
\end{tabular}

Numbers represent Mean \pm S.E, $*$ mean significant $\mathrm{p} \leq 0.05, * *$ mean significant $\mathrm{p} \leq 0.01$

\section{Discussion}

Estrogen primary function in the male reproductive tract appears to be the regulation of fluid reabsorption in the efferent ductules via the estrogen alpha receptor $(E R \alpha)$. Disruption of the receptor or by treatment with anti - estrogen results in dilution of caudal epididymal sperm, disruption of sperm morphology and inhibition of sodium transport and subsequent water reabsorption and eventually leads to decrease fertility (Iguchi et al., 2001).

Could cimetidine be acting via reduction in gonadotropin secretion? There is conflicting information whether or not cimetidine affects plasma gonadotropins levels (Winters et al., 1979) if some effects are present they are little in the testis, for example Leydig, Sertoli and germ cells show none of the stage related effects of classical gonadotropin withdrawal (Russell and Clermont 1978).

Long term treatment with cimetidine has not been reported to reduce weights in rats (Rabaset al., 1981; Leslie et al., 1981), The present study shows similar results, however in most of the previous studies, the mean value of testis weights in cimetidine treated animals is always numerically below that of controls although with a statistical comparison with controls the mean level does not reach the level of significance. This conflicts with our results as there is an increase in testis weight in G3 and G4. We note also that testis weight is not a sensitive parameter for demonstration of toxic effects (Berndtson et al., 1989). This study is in 
agreement with the well known effects of cimetidine on accessory sex organ weights which has been reported before.

Our findings may reflect weak anti androgenic properties of cimetidine acting to block DHT from binding to the androgen receptor and thus preventing DHT action (Winters et al., 1979). A second possible mechanism of cimetidine may be the result of chronic antagonism of the $\mathrm{H} 2$ receptors. Vascular smooth muscle cells of the body are generally known to be $\mathrm{H} 2$ responsive (Rabe and Serfain 1997).

The decrease in total sperm count among treated groups is in agreement of previous study (Wang et al., 1982), this may be due to depletion of germ cells as noted in previous studies.

We agree with (Lui et al., 2000) when he mentioned that the increase in FSH levels in all treated groups is due to decreased spermatogenesis and depletion of germ cells.

Some previous studies reported decreased testosterone levels in cimetidine treated rats (Parker et al., 1984), a finding which is not supported by the present study and also supported by some other previous studies (Leslie et al., 1981 ; Kingge et al., 1983 ; and Pinelli et al., 1987).

\section{Conclusion:}

Cimetidine has hazards on male reproductive function while estrogen dose not play any role to abolish this action.

\section{References}

1) Berndtson WE, Neefw C, Foote RH, Amann RP. Optimal replication for histometric analysis of testicular function in rats or rabbits. Fund Appl Toxicol,12: 291-302 (1989).

2) Chen $\mathrm{H}$, Chandrashekar V, Zirkin B. Can spermatogenesis be maintained quantitatively, in intact adult rats with exogenously administered testosterone? Androl, 15:132-138 (1994).

3) Hess RA, Carnes $K$. The role of estrogen in testis and the male reproductive tract: A review and species comparison. Anim. Reprod, 1: 5-30 (2004).

4) Iguchi $\mathrm{T}$, Watanabe $\mathrm{H}$, and Katsu $\mathrm{Y}$. Developmental effecs of estrogenic agents on mice, fish and frogs: a mini - review. Horm Behav, 40: 248-251 (2001).

5) Kingge U, Dejgaard A, Wollesen F, Ingerslev O, Bennett $\mathrm{P}$, Christian Sen P. The acuate and long term effect of the H2Receptor antagonist cimetidine and ranitidine on the pituitarygonadal axis in men. Clin Endocinol, 18: 307-313 (1983).

6) Korach $\mathrm{KS}$. Insights from the study of animals lacking functional estrogen receptors. Science, 266: 1524-1527 (1994). 
7) Leslie GB, Noakes DN, Pollitt FD, Roe FJC, Walker TF. A twoyear study with cimetidine in the rat: assessment for chronic toxicity and carcinogenicity. Toxicol Appl Parmacol, 61: 119-139 (1981).

8) Lubahn DB, Moyer JS, Golding TS, Couse JF, Korach KS, Smithies O, Alteration of reproductive function but not prenatal sexual development after insertional disruption of the mouse estrogen receptor gene. Proc Natl Acad Sci USA, 90: 11162-1166 (1993).

9) Lui ZR, Franca, Marcelo C. Estlea Sasso Cerri, Anilton Vasconcelos, Luciano Debeljuk, and Lonnnie D, Russell. Cimetidine (Tagamet) Is a Reproductive Toxicant in Male Rats Affecting Peritubular Cells. Biology of Reproduction, 63: 14031412 (2000).

10) Luna LJ. Manual of histology staining methods of armes forces institute of pathology $3^{\text {rd }}$ ed New York, Balkiston division, Mc Gram. (1968).

11) Meistrich ML, Hughes TJ, Bruce WR. Alteration of epididymal sperm transport and maturation by estrogen and testosterone. Nature, 258: 145-147 (1975).

12) Nie R, Zhou Q, Jassim E, Sannders PT and Hess RA. Differential expression of estrogen receptors alpha and beta in the reproductive tracts of adult male dogs and cats. Biol Reprod, 66: 1161-1168 (2002).

13) Noakes DE and Parkison DJ. Arther's, Veterinary reproduction and obstetrics. $8^{\text {th }}$ ed Gary Cw England (2001).

14) O'Donnell L, Stanton $P$, Wreford N, Robertson D, McLachlan R. Inhibition of 5- $\alpha$ reductase activity impairs the testosterone dependent restoration of spermatogenesis in adult rats. Endocrinology; 137:2703-2710 (1996).

15) Parker S, Udani M, Gavaler J, Van Thiel D. Pre and neonatal exposure to cimetidine but not ranitidine adversely affects adult sexual functioning of male rats. Neurobehav Toxicol Teratol, 6: 313-318 (1984).

16) Pinelli P, Tirivulzio S, Columbo R, Cocchi D, Faravelli, R, Caviezel F, Galmozzi G, Carvallaro R. Antiprostatic effect of cimetidine. Agents Actions, 22: 197-201 (1987).

17) Rabas S, Paul H, Pollowk, Janetschek G, Jacobi G,. In studies on the anti androgenic effects of cimetidine versus cyproterone acetate in rats. Prostate, 2: 163-174 (1981).

18) Rabe KS, Serfain WE. Histamine, Bradykinin, and their antagonists In: Hadman JG, Molinoff PB(eds) Goodman and Gilman's: The pharmacologic bases of therapeutics Ninth Ed., Ch.25. New York: McGraw-Hill,: 585. (1997). 
19) Robertson KM,O' Donnell L, Jones ME, Meacham SJ, Boon WC, Fisher CR, Graves, KH, McLachlan RI, Simpson ER. Impairment of spermatogenesis in mice lacking a functional aromatase (cyp19) gene. Proc Natl Acad Sci USA, 96: 7986-7991 (Abstract) (1999).

20) Russell LD, Clermont $Y$. Degeneration of germ cells in normal hypophysectomized and hormone treated hypophysectomized rats. Anat Rec, 187: 347-66 (1977).

21) Sakamato J, and Hashimoto K... Reproductive toxicity of ary Lamide and related compounds in mice effect on fertility and sperm morphology. Arch. Toxicol, 59: 201-205 (1980).

22) Sannders PT, Millar MR, Mapherson S, Irvine DS, Groome NP, Evans LR, Sharpe RM, and Scobie GA. ER beta1 and ERbeta2 splice variant (ER beta cx/beta2) are expressed in distinct cell populations in the adult human testis.J Clin Endocrinol Metab, 87: 2706-2715 (2002).

23) Toda K, Okada T, Takeda K, Akira S, Saibara T, Shiraishi M, Onishi S, Shizuta Y. Estrogen at the neonatal stage is critical for the reproductive ability of male mice as revealed by supplementation with the $17 \mathrm{~B}$ estradiol to aromatase gene (cyp 19) knockout mice. J Endocrinol, 168:455-463 (2001).

24) Wang $C$, Lai $C$, Lam $K$, Yeung $K$. Effect of cimetidine on gonadal function in man. Br J Clin Pharmacol, 13: 791-794 (1982).

25) Wilson JD. Sexual differentiation. Annual Review of physiology; 40: 279-306 (1978).

26) Winters $S$, Banks J, Lorian $D$. Cimetidine is an anti androgen in the rat. Gastroenterology, 76: 504-509 (1979).

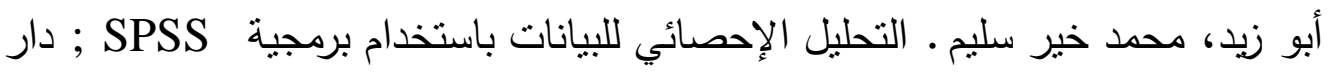

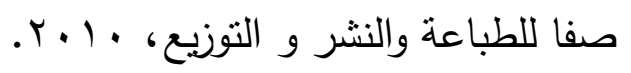

